\title{
War on Terror in Regional and Trans-Regional Context
}

\author{
Jamil Ahmed Khan PhD \\ SUIT 113, First floor, the Plaza, Near Do Talwar, Block 9, Kehkashan Clifton, Karachi, 75500 \\ Jamilkhan62@yahoo.com
}

\begin{abstract}
Terrorism from the longer time has attracted many of the experts in history and present times to work on it with a quest to find out the causes and look for its cure. This article, I have made an endeavor to discuss terrorism from different aspects examining the history of the creation of different terrorist organizations; the research analyzes the latest Talibanization phenomenon. Before and after the 9/11 tragedy, there had been many discussions that seemed to have pondered upon "Good Talibans" and "Bad Talibans", the study intends to make sense to both these terminologies by giving each of it sufficient time to have a clear understanding by examining through rich literature that illustrates both these terminologies candidly and categorically. The work on this topic is one of its kind that is unbiased that not only explains the mistakes being committed by the countries where the rogue elements like Al-Qaida and Taliban prevailed or are still prevailing, Though Afghanistan is in the focus but it has also pointed out the wrong policy decisions in different phases of time by the United States of America during the fight against terrorism.
\end{abstract}

Indexing terms/Keywords: Terrorism, Extremism, Taliban, ISIS, Mujahedeen, Politico-Islam, World Peace, Islamo-phobia

Subject Classification: Social Sciences

Type (Method/Approach): Analytical method based on neutral approach and in the historical perspective

Supporting Agencies: Sindh Police

Language: English

Date of Publication: 11.07.2018

DOI: $10.24297 / j s s r . v 12 i 2.7451$

ISSN: 2321-1091

Volume: 12 Issue: 2

Journal: JOURNAL OF SOCIAL SCIENCE RESEARCH

Website: https://cirworld.com

This work is licensed under a Creative Commons Attribution 4.0 International License. 


\section{Introduction}

Terrorism is a common enemy not only in the context of Afghanistan or Pakistan but for the entire world. Many researches and politicians argue that Pak-Afghan is an epicenter of terrorism which include terrorist of all hues and colors. It is high time that the world powers should find common grounds to unite on one point agenda "fight terrorism" with multi-pronged approaches. Proxy war by using terrorism as a tool of foreign policy should be identified and subdued by the community of nations. An endeavor is made to touch upon multiple factors attributing to the cause and symptoms of terrorism around the globe chiefly in Pakistan and Afghanistan.

\section{Materials and Methods}

- Material: Library, online journals, Periodicals, Articles, Statements of experts and politicians besides Authors own experience as a Diplomat

- Method: Analytical with neutral approach by examining literature in the backdrop of professional experience in the relevant field

\section{Results and Discussion}

Extremism became part of socio economic culture in the developing countries chiefly in Muslim majority. We have noticed that the political parties could not perform as they were expected to minimize and subsequently control extremist behavior. Historical perspective of terrorism is found to be in congruence of global politics and strategic planning of big powers. In the current scenario terrorism besides other means is also used as proxy war.

\section{BACKGROUND}

The main study of this research is based on evolutionary pattern of terrorism to understand propagation, logic and design of fundamentalism and its connection with religion. 9/11 attacks revealed state-sponsored terrorisms adjacent with terrorist and religiously motivated groups. Constant rise in number of terrorist activities significantly correlate the violence with religion and geo-political situations which established the necessity to prop up fundamentalist supporters in the first two decades of 21 st century.

It was a time of increased tensions between Afghanistan and America that got the situation worst because of the fact that Pakistan agreed on providing logistical support to USA for fighting against terrorist elements in Afghanistan. Most of the parts of NWFP were mainly controlled by the Taliban, which is now known as Khyber Pakhtunkhwa and FATA and these are supported by various other militant groups that are united under the umbrella of Deobandi maslak's ideology with the name Tehrik e Taliban Pakistan (TTP) (Hussain T. , 2009) [1]

\section{SOME ISLAMIST GROUPS THAT ARE INVOLVED IN TERRORISM}

1. Al Qaeda/Pakistan Taliban (Qari Zafar/ Baituallah Mahsud Group)

2. Sipah-e-Sahaba Pakistan/ Lashkar-e-Jahangvi

3. Harkat-ul-Jehad-e-Islami (HuJI)/Harkat-ul-Mujahedeen Al-Aalmi (HuMA)

4. Sipah-e-Muhammad Pakistan

5. Tahreek Lashkar-e-Islami Muhammadi

6. Jundullah

7. ISIS 
(Unknown, Institute for Conflict Management, 2001) [2]

Taking into consideration the terrorism on national level; its idea is one of its many kinds. Particular regions have their own regional interests that come under regionalism and there the geo-politics is the central and fundamental ideology surrounded by political ideology in order to increase political influence. These are the demands that result into the factors like the movements for separatism, independence, sovereignty or political autonomy. The past days these movements were held for the same purpose of being liberal and/or independent but presently, the same practice seems to be turned into a violent attitude. Specially, in Baluchistan, Province of Pakistan, we have witnessed such sort of actions from the nationalist extremists. There are many other prevalent examples that pave the way for criticism to the complex scenario in the province. This is, even though, a type of terrorism that in my point view is controllable as it starts in the boundary of a country. If the state takes its moves strategically and sensibly so one can fulfill the demands and clarify their misunderstandings rather than being threatening, then the probabilities of them being violent can be lesser.

The problem will become more complicated once Baluchistan Liberation Army categorized as terrorist organization or nationalist terrorist underneath the army stress of the state retaliate after seeking support from (Indian Intelligence Agency).

Indian Agency finds itself one of the opportunities to create disturbance and violence in Pakistan and it is succeeding in its stretegy. The Baloch Liberation Army (BLA) grievances not that hard to be addressed if civil and the military institutions sink in each others thought. The rebellious "Balochis" may be included in to the main stream after laying down their weapons if they're given trust that no discrimination would take place in terms of their rights and in terms of un-warranted military movement in crushing the Baloch rebels which caused alleged disappearance of many "Balochis" involved within the movement. Having the right approach, Pakistan can delineate the involvement of Indian intelligence agency through winning over the hearts and minds of "Balochi" people and by offering higher package of finances that might smoothen the condition for better employment and improvement in Baluchistan. In nutshell.

Pakistani government wishes to have interaction in a broader perspective of the people from all walks of life in Baluchistan so as to cope with the issue of national terrorism.

The most prominent national terrorist organizations that have emerged as the threatening forces for their respective regions are:

- Baluchistan Liberation Army (BLA)

- eTA

- EOKA

- PartiyaKarkerên Kurdistan (PKK)

- Armenian Secret Army for the Liberation of Armenia (ASALA)

- Front de libération du Québec (FLQ)

- Provisional Irish Republican Army (IRA)

- People's Mujahedin of Iran (MKO)

- Tamil Tigers (LTTE)

- Ukrainian Insurgent Army (UPA)

- Wawelberg Group

- Lehi

- Irgun 
- National Bolshevik Front (NBF)

(Unknown, Institute for Conflict Management, 2001) [2]

\section{PAKISTAN IN CONTEXT OF TERRORISM}

The Pakistan supported Taliban in Afghanistan who groomed themselves in the context of organizational structure. Meanwhile aforementioned specific small and large Islamic organizations emerged in Pakistan, with the continuous successful terror plans completed by using the then Afghan-Taliban group. In line with the present facts, there are forty eight religious and extremist groups of different sizes are operating in Pakistan. (Unknown, Institute for Conflict Management, 2001) [2] Each one of the groups follows its own sets of rules.

In addition to terrorist groups, here are some extremist groups operating in Pakistan:

1. Al-Rashid Trust

2. Al-Akhtar Trust

3. Rabita Trust

4. Ummah Tamir-e-Nau

\section{MEDIA}

Present time's media houses wavering policies have proved that moral social responsibility is now story of the past and moral values are acknowledged in case of rivalry only. Viewing media-violence leaves unhealthy affects on viewers ranging from anti-social to serious level of criminal hostility. An overwhelming consensus shows that often general public gets accustomed to accept violence as a solution to all problems. Media has a huge role in promoting a particular agenda to create a specific mindset accordingly. Arab media has long been found inciting people to react against West, specifically United States of America, Israel and to some extent, the United Kingdom as well. (Kellner, 2015) [3]. Exemplifying the Arab intellectual naming Abd AlHamid Al-Ansari who is (Former Dean of Islamic Law, Qatar University) in the year 2005, on Bahrain TV broadcasted a program in which he said:

"The media houses of our time should be named after terrorists and deserve to be called 'Terrorist Media' as they feed our youngsters with the ideas which do nothing but rising hatred and extremism"

\section{INTERNATIONALIZATION OF TERRORISM}

Since the time United States got discovered by Christopher Columbus on October 12, 1492, People used to stay there for thousand years before the migrants from Europe commenced to arrive. Most of the migrants had been from England after $16^{\text {th }}$ century. They carved their colonies and villages and started out to settle their lives. This is precisely how this country was built as a nation in the beginning (Stokes M. , 2002). [4]

At some point in 1960's Anti-Western perceptions emerged and exceptional moves started to run against West, specifically inside the middle-East.

The idea of higher trajectory political missions through violent use of power speeded widely. It is the phase while a collection of religiously influenced terrorists internationalized terrorism, making terrorism a worldwide dilemma.

What history reveals is the fact that it was Palestine that became the catalyst for undertaking violent activities in 1970's. Palestine became considered to be the promoter of rebellious practices all over the world. It formed secular movements that focused innocent civilians. Popular front for the Liberation of Palestine 
(PFLP) that was established in the year 1967 by, George Habash was allegedly involved innumerous attacks that took place in Israel since September 2000, the organization that targeted innocents on a large scale.

After the Arabs lost the war with Israel in 1967, Palestine become aware of the fact that Arabs have not been strong enough to combat towards military of Israel. Meanwhile, the other lessons from different movements helped Palestine to get rid of guerrilla war and work on something bigger. The militant group of Palestine made use of technological advancement to strengthen their struggle worldwide. They modernized their setup with a better communication system. With the passage of time, they brought evolution in their structure at a significant level. It was a group of people from Palestine that was allegedly involved in several attacks which include the attacks on Israeli athletes at the time of Olympic Games held in 1972.

The last however not the least to say is the Abu Nidal organization (ANO) which was more violent than its predecessors. ANO was commanded by Sabri al-Banna. This terrorist group broke all the preceding records of the anti-West and Israel and attempted furious attacks that affected around 900 people in 20 unique international locations. In one of the incidents, Abu Nidal organization had hijacked Pan AM plane at Karachi Airport on 5th September 1986 that ended with the loss of life of twenty-two people and injury of hundred and fifty passengers. The ferocious group of terrorists from Abu Nidal organization disguised into the security vehicle and made their way towards the aircraft during the time when passengers were boarding. The blockade went on for over 16 hours until one of the terrorist openly fired on the passengers which made the Pakistan security forces to storm into the plane. All of the terrorists were caught from the spot and later convicted in Pakistan.

In the year 1979, the Iranian Islamic Revolution created a fear of revolutionary Shia in most of the West and Arab world. This was the time period when quick changes have been witnessed, making it a turning factor for international terrorism. During the period of 1979 to 1989 there has been a rise in terrorist organizations on a higher scale and the ultimate reason behind that was the soviet war of Afghanistan and the resultant anti-Soviet Mujahedeen war.

Moreover, the emergence of Syrian Arab Republic, as an independent state occurred subsequent to the Second World War that was followed by decades of French ruling resulting in the nationalist unrest. Before that, the land of Syria was dominated by the Ottoman Empire. The territory has outstanding significance in terms of founding the Christianity and Islam, as major events regarding that occurred over a period of time. One of those events may also include the war among Muslims and Christians and also the hatred of the Mangol invasion from the center-East.

While discussing about the losses, one cannot ignore Pakistan and Afghanistan who mainly faced difficult situations because of Taliban, AI-Qaida, ISIS and different militant groups in form of lives and monetary losses. But the reality is when such extremist militant organizations saw that the government is weak politically in Arab nations after Sept. 11; they showed disgusting powers and extremism to them. Iraq, Yemen, Libya, and the ongoing conflict in Syria are the best examples to understand the problem of terrorism and its dynamics.

\section{FUNDAMENTAL CAUSES OF TERRORISM}

Extremists are much more likely to come from the places where there are difficult and unpredictable circumstances and therefore it becomes incubator for rise in Extremism. Modernization and globalization has been the main factor that has weaken the countries of the world, people of the underdeveloped countries are at risk, in which political and social structures are scarce in basic needs and fundamental rights to majority portion of the population. Lack of constitutional protection coupled with associated laws such as freedom of religion, freedom of speech, freedom of the press, and independent robust judiciary in its true sense is not prevalent All these factors attribute to the potential for religious extremism. (Kressel, 2007) [5] 
Discussing about the religion there comes the Judaism which, in the history is considered to be the most peaceful Abrahamic religion. Even now modern Judaism no longer advises violence or extremism. However, Judaism has nevertheless a list of pointlessly murderous battles with the rightful native population, sufficient number of statements prevailing in the Bible that can be used to support violence and aggression in the name of religion.

In Jewish records, nations performed compelled conversion altogether. In the present time terrorist incidents have targeted such areas where there is unique religious significance for Jews in Israel; over there, struggles have been made to control that land. It is on this context, extremist organizations have done terrorist movements against Palestinians.

The Haredim (ultra-conservative Orthodox Jews) are increasing in number. They are trying to aggressively separate the genders, enforcing strict rules of wearing specific dresses on people and most importantly putting bans on accessibility of reading material through internet. This is the case even though the government of Israel speaks out against extremism. (Crabtree, 2016) [6]

\section{POLITICAL EXTREMISM}

It is a form of extremism that is a significant threat to societies as people at large feel less protected and less shielded as compared to some other groups of the societies. It creates a distinct form of inequality stirring the oppressed groups to grow to be strongly violent, inducing them to indulge into various rogue activities. They act both as political entities or they are supported by political parties. This kind of extremism is primarily based specially on ethnicity, racism and other such lingual or cultural differences.

If we see the article 19 of the constitution of Pakistan 1973, we will find out there are a number of restrictions imposed by the law, in which protection for freedom of speech is provided with a good explanation. It is something that has been designed keeping in mind the dignity of Islam, the integrity and protection of Pakistan and other such factors. Like many other constitutions, the constitution of Pakistan too is a social contract between the state and the people. (The constitution of Pakistan) [7]

In Pakistan this freedom of speech has been allowed to be exercised with reasonable constraints imposed by using designed regulation which in terms limits the spirit of the word freedom of speech itself. This sort of limit will have both negative as well as positive affects. In my view freedom of speech is the best source used to eliminate the evils of the society or country through dialogue as long as it does not create a scenario of anarchy or violence. Speech itself is a non-violent tool if applied to discuss and find a solution. A society that is stricken by extremism has to suffer, each economically and socially. Economic losses are capable of drowning societies in a pool of economic recession. They cause organizations to close down, giving rise to unemployment. The poverty graphs start growing and hence the society faces the consequences in terms of its economic depression if not failure.

On the other hand, it impacts the society socially too. People turn out to be frustrated and hence get involved in numerous rogue activities. The crime ratios begin to growth and the corruption amongst masses emerges as a common feature. People suffer mentally and psychologically as well. The ones who've less or no involvement in any religious or political matters turn out to be even worse criminals when they lose their loved ones for no purpose or fault of their own.

\section{POLITICS AND ISLAM}

Islam is characterized as a divine doctrine based totally on organic religious structures wherein social, political, financial and cultural entities are self reliant. The dynamics of the relationship between Islam and politics determines on realization and idea of welfare oriented life where basic needs are catered for. Politics in Islam also can be defined as a practice with moral beliefs and political spirit. At present instances nature of 
politics in Islamic nations has been re-shaped in contrast with Western Democracies. Touqir Hussain, a former diplomat of Pakistan, who has also served as an ambassador for Japan, Brazil and Spain writes in his article that the year 1979 is found to be the unique in the history of Islamic world. He keeps writing that Pakistan, Iran and Afghanistan acted as epicenters and tributaries. In the same year Iranian revolution occurred that reshaped the dynamics of the center-East, affecting Persian Gulf to its maximum. In Pakistan, General Zia-ul$\mathrm{Haq}$ in his dictatorial regime manuplated, through the use of force, the democratically elected Prime minister, Zulfiqar Ali Bhutto by lodging a military coup and removed using Islamization as a tool beside other things. (Hussain T. , 2009) [8]

If we look up the losses in monetary development of Pakistan as a result of terrorism and the continuous war in Afghanistan suggests that terrorism has affected Pakistan's economy adversely. The effects include poverty, destruction of infrastructure, reduction in foreign direct investment, tourism, Capital flow opportunity losses and more. It was found out from the cited reference that terrorism has caused Pakistan a loss of $1.6 \%$ of its Gross Domestic Product. It also highlights that the $1 \%$ increase in terrorist activities cause the $0.39 \%$ loss of GDP in Pakistan (Hyder, Akram, \& Padda, 2015). [9]

\section{HOW TERRORISM WORKS}

Terrorist organizational structure and hierarchy portrays precisely like a common business enterprise. Terrorist organizations like other business organizations have their strategic goals and to achieve those goals they choose leaders for them to make selections and reach their strategies. But actually, its commitments are different from an ordinary organization. It has certain levels of commitments which include passive support, active support and leaders to run operations smoothly. Consequently, having the same pattern to work, Al-Qaida, Taliban and other extremist organizations of South Asia that basically belong to Afghanistan and remained fortified generally in mountainous areas of Pak-Afghan borders.

The militancy against the Pakistan behind the veil of Islam certainly speeded-up a huge effect at the demographic, monetary, social, cultural, mental and over all behavior of Pakistani population. FATA, which is the most ignorant tribal place of Pakistan, has observed the worst ever poverty, illiteracy and unemployment over decades. The crown prince of Saudi Arabia during his visit to United States in March 2018 interacted with famous media group and pounded no words in accepting that politico Islam got misused during cold war by the west with the help of Saudi Arabia.

The final war that culminated in 1989 which was fought in Afghanistan by mustering Mujahedeen from many of the Muslim countries of the world - all funded by USA in conjunction with its allies chiefly Saudi Arabia. According to Islam, politics and religion are crucial because of the fact that Islam explains governing mechanism to run a country as a welfare state, further; Islamic Shariah unifies religion with politics. This is so unfortunate that extremist groups emerged due to Afghan warfare use the name of this holy religion ISLAM for their secret political motives. They are attempting to get peoples' sympathies in the name of Islam however their entire effort turns into confrontation, resistance and rebellious activities that have nothing to do with Islam. It is very important to notice that their activities are usually based upon extremism for political agendas which begin in the name of religion but ends on politics. The root cause of uprising religious extremism and emergence of aggressive ideology has been illustrated through several examples; mentioning rational and irrational factors e.g. political instability, poverty, illiteracy, foreign meddling, vulnerability to different disasters, etc within each country under the backdrop of religious extremism. Most importantly, socio-economic downfall matters a lot; it deprives people off from the primary needs of life, they grow to be annoyed and aggravated, and easily fall prey within the hands of extremists in which their basic needs are taken care of in addition to indoctrination of their minds; that have been thriving for the affection, with extremism, an instance of which has occurred in Afghanistan while fighting a war against USSR troops. 
Similarly, ideas and philosophies that are not practiced by different members of the society and are imposed on some individuals or groups that often worsen the situations which might be prone to extremism in lots of approaches. Currently, the world is going through the most unfavorable and harsh type of extremism which might be a combination of religious, Ethnic and Political Extremisms. In reality all three are interconnected and their root cause is prejudice toward minorities and race discrimination. Even though Pakistan's $97 \%$ population is Muslim but the entire Muslim population does not belong to the same religious Sect. Thus religious, sectarian and ethnical variations have been producing the extremism which often turns into political actions.

It seems like world's prejudice Media abhors the Islam, declares and propagates and shows the things mainly against Islam and hides issues that aren't in its favor. That is the media which began Islamo-phobia and made the Muslim communities disheartened. As a result, Muslims became enraged; resultantly, they are being violent and constantly making efforts to prevent this propaganda. And most of all that the laws and legal guidelines made by the Western countries consisting of UNITED NATIONS for freedom of speech rights and the misuse of freedom of speech rights are designed in a way that they have very poor strategic approach.

So it would be unjustified to expect from a few nations only for putting efforts to set up peace and harmony. Internationaly, Peace maybe restored when rules and strategies are there to assist and control t he situation, when political, sectarian, ethnic and economic wars have ended and peace messages are sent from neighboring borders. How can the peace be maintained in a situation where countries are given tough time by the countries who are against them and they supply equipments and arms on the basis of racial, sectarian and religious problems.

\section{HOW EXTREMISM DISRUPTED THE WORLD PEACE ORDER OVER TIME}

Any disease that isn't controlled on time worsens. Extremism also was like cancer that was supposed to have been cured and handled when it commenced to reveal its colors. Unfortunately it was being ignored mostly for global political reasons; therefore, it became violent and barbaric. In a very brief span of time, it caught many countries and societies in distinctive ways. In this war, world has witnessed the disgusting types of terrorism and terrorist attacks. Millions of humans have lost their lives without knowing the actual reason behind that. The world had to bear a massive financial loss. Then there are countries that have suffered in this war with the maximum losses.

An important question although is how and why religious extremism has spread everywhere in the world with the highly negative effect that it has become a conduit on the world peace order nowadays. Reza Aslan relates nicely with the scenario that "no religion is peaceful or violent; it is the people who attach their versions of meaning to religion".

It is a distorted notion that some of the most terrifying terrorist groups are using the name of Islam and calling the barbaric acts of killing masses as Jihad. What they're doing, can never be termed as Jihad because it does no longer satisfy even the basic criteria for Jihad. That's what I have tried to emphasize on the reality that no Prophets or The Messengers of God, from Adam (Peace be Upon Him) and Muhammad (Peace and mercy be always upon Him) have taught to kill everyone pointlessly. Islam does not even allow forcing each person to practice Islam. Islam is the simplest religion that has defined properly the rights of minorities and freedom to practice their faith in their own respective way.

The role of media; again it has to be focused because as mentioned earlier, it is spreading hatred. There is the need of the laws and regulations about hate speech that are advancing the vicious thoughts and support extremism. The hypocrisy of West on the hate speech and the freedom of speech laws should be eradicated. They are projecting the point to the degree that when they talk about different religions, they advantageously call it the "freedom of speech", however when others utilize the similar benefit, they call it "hate speech". It is 
hence the critical need of time that countries must end such dichotomy guidelines and diminishes propagating hate through their prevailing media.

The societies that have terrorism within are affected by terrorism as a whole. They not only suffer economically but socially as well. Due to the losses economically they lose their jobs; unemployment ratios go higher, income per capita falls and people are merely able to access the basic necessities of their lives, sometimes that accessibility become equal to impossible. People become frustrated because of their difficult economic survival. They get psychologically distracted by the fear of being targeted in attacks. And once anybody is attacked they become violent as a result of the pain of losing their loved ones and their families for no reason. In today's world nobody is willing to give a second thought to the painful situation that is there for people to suffer; neither the terrorists understand their cruel conduct or the victims for being targeted of such atrocious activities. Resultantly people have gone abnormal in their behaviors.

If we take the example of Nigeria, Syria, Iraq, Afghanistan and Pakistan; it comes on the conclusion that if any problem is not solved timely, it becomes fatal like delayed cure for any disease that is exactly happening with the extremism.

In order to measure the causes of terrorism and spurring extremism, one must look into the details of how the common people respond against the inequality, lack of justice, discrimination, economic depravity, and socioeconomic crises and so on and so forth. It is a general fact that the over suppression, ignorance and injustice is slowing down the stability within societies. Over all my focus in this article was on the fact that we must point out the existing causes and loopholes within the policies that are there in use in today's world. It also stresses on the fact that the diplomatic response of a country also matters in solving this issue.

There is the trend of hiding the actual facts and figures in today's world due to which, those who can identify the loopholes are unable to do their work efficiently, they have very limited access to the material they need. The propagation of NEWS based on false facts or overstatement is common practice. There is no such platform that could correct, accept or deny the things whether they are based on truth or unauthenticated sources.

As the time is passing the nexus between the political disputes and the rising trend of terrorism has been observed to become stronger. The greed for power, money and status has made the competition that is difficult to win for the one who is honest and wants to serve the state. Due to this political instability, frustration is spurred further which in turn gives birth to the terrorism oriented minds.

There is a clear partition in the world with reference to religion. It seems that, it is portrayed as there are only two religious paths being firmed today, one is Islam and the other is Anti-Islam. This clear division provoked the war of words, at first, followed by war of weapons. This is mainly why this war criticizes the image of Islam so extremely.

\section{CONCLUSION}

One can conclude with the thought that this war between Islam and Anti-Islam brought up the terrorist organizations with an approach like that of the Al-Qaida and its affiliates that has its roots in Afghanistan and offshoots in Pakistan.

War in Afghanistan has resultantly inflicted huge losses on USA in terms of main material and finances. Its failure in Afghanistan despite huge resources dedicated, but US had to suffer in taking back home a large number of body bags of soldiers and contractors and also brought constraint in the economy. Further, the phenomenon of Talibinization, it has taken upward trajectory comparatively and has attend ferocious dimension with the augmentation of other affiliates. America seems to have gotten frustrated with the failure and that might be the main reason due to which it changed its policies. 
What statistics show is that in Pakistan around 60844 people died between the tenure of 2013 to 2016 only because of war on terror.. Such terrorist attacks caused 3906 deaths in the year 2008 alone. Apart from Pakistan, people in Afghanistan also suffered the huge losses in terms of life and property during this phase of war. Explosions based on advance technology and tactics caused around $37 \%$ of the population to lose their lives. (Unknown, Afghanistan NGO Safety Office, 2011) [10]

Looking and analyzing terrorism globally, many initiatives have been taken to eradicate it. Like in 2004 there held a round table conference that took place in Moscow that holds a great importance because of the fact that countries from all over the world attended it to design strategies and solutions to restore the world peace in the context of terrorism.

In my opinion, the preferred solution to deal with the current situation is to be united for the sake of humanity. The differences cause nothing but conflicts which lead to wars catastrophe. War has never been a sole solution to the problem but mostly becomes an infinite vicious circle of the problems itself, opening a Pandora Box of complication and complexities. To avoid the war and its collateral damage, the world needs to unite on one point agenda to completely restore the world peace order. The world needs to be assured of better ways of dealing with problems and differences than killing each other, as John Steinbeck said: "all war is a symptom of man's failure as a thinking animal".

Data Availability Data analysis via books library, Research of M.phil and Phd desertation in addition to related periodicals, articles and journals on social sciences

Conflicts of Interest: No conflict of Interest exits

Funding Statement: Self finance

\section{Acknowledgments}

In writing this research article I was supported by few of my friends and mentors.

I have to express my appreciation to Prof. Dr. Muhammad. Ahmed Qadri, my research advisor for sharing his pearls of wisdom with me during the course of this article. Further I am thankful to my Supervisor for providing me insight that greatly assisted the write-up, although he may not agree with all of the interpretations provided in this manuscript.

I am also immensely grateful to IG Sindh Sindh A.D. Khwaja, who provided me some facts related to the topic. I appreciate his cooperation and coordination.

Also I acknowledge the assistance rendered by Miss. Paras Qurban during the course of compilation and composition; she is not the listed author but she made a contribution to the research and manuscript. It may be in the fitness of the thing to acknowledge the administrative support of Miss. Saima Nathoo who took care of all the logistics including freshly brewed coffee and tea.

Lastly I am grateful to all those professionals who shared their research journals online/offline regarding their manuscript, although any errors are my own and should not tarnish the reputations of these esteemed professionals. 


\section{References}

1. Hussain, T. (2009). Post-1979 Pakistan: What Went Wrong? The Middle East Institute Viewpoints: The Islamization of Pakistan, 1979-2009. Middle-East Institute.

2. Unknown (2001), South Asia Terrorism Portal, Institute for Conflict Management http://www.satp.org/satporgtp/countries/pakistan/terroristoutfits/group_list.htm

3. Kellner, D. (2015). Media Spectacle and the Crisis of Democracy: Terrorism, War, and Election Battles. Routledge.

4. Stokes, M. (2002). The State of U.S. History. https://www.questia.com/library/102287679/the-state-ofu-s-history

5. Kressel, N. J. (2007). "Killers in Every Faith: Christians and Jews" digital location 1048.

6. Crabtree, V. (2016). Islamic Violent Fundamentalism and Extremism.

7. Unknown The constitution of Pakistan: Freedom of speech, etc. (n.d.). retrived on may 272018

8. Hussain, T. (2009). Post-1979 Pakistan: What Went Wrong? The Middle East Institute Viewpoints: The Islamization of Pakistan, 1979-2009. Middle-East Institute.

9. Hyder, S., Akram, N., \& Padda, A. U. (2015). Impact of Terrorism on Economic Development in Pakistan. Pakistan Group Review .

10. Unknown, Defence.pk, (2011). Afghanistan NGO Safety Office. 